\title{
CRITICAL FACTORS IN DEVELOPING SUSTAINABLE FOOD PACKAGING
}

\author{
Nyayu Lathifah Tirdasari*)1, Andina Oktariani*), Dikky Indrawan*), and Nur Hasanah*) \\ *) School of Business, IPB University \\ Jl. Raya Padjajaran, Bogor 16151, Indonesia
}

\begin{abstract}
The sustainability issue has pushed the food industry, continually looking for new materials to reduce and replace plastics in their packaging. However, the recent development of novel materials is still less satisfactory due to different involvement from different vital players such as government, society, and industry. This paper analyzed the critical success factors of new material development for food packaging based on different key players, involvements, and interests. A survey was conducted by the authors to gather information related to the development factors and the participation factors based on the three key players. This research employed descriptive quantitative design. This design allows research to collect and describe the found clusters and factors. The results revealed that the critical success factors are classified into five clusters, namely technical substitution, technical drivers/barriers, application barriers, cost barriers, and raw material supply barriers. Differently from developed countries, the critical vital players' participation, especially from the government, was essential in developing new material for food packages.
\end{abstract}

Keywords: critical success factor, descriptive quantitative, food industry, food packaging, sustainability development goals

Abstrak: Isu mengenai keberlanjutan telah mendorong industri pangan untuk terus mencari material baru dalam rangka mengurangi dan mengganti plastik dalam kemasan produknya. Namun, perkembangan materi baru saat ini masih kurang memuaskan karena adanya keterlibatan dari berbagai pemain utama seperti pemerintah, masyarakat, dan industri. Penelitian ini menganalisis faktor penentu keberhasilan pengembangan bahan baru untuk kemasan makanan berdasarkan berbagai pemain kunci, keterlibatan, dan minat. Survei dilakukan oleh peneliti untuk mengumpulkan informasi terkait faktor pembangunan dan faktor partisipasi berdasarkan ketiga pemain kuncitersebut. Penelitian ini menggunakan analisis deskriptif kuantitatif. Analisis ini mendeskripsikan data klaster dan factor yang telah terkumpul. Hasil penelitian menunjukkan bahwa faktor penentu keberhasilan diklasifikasikan menjadi lima cluster, yaitu substitusi teknis, pendorong / hambatan teknis, hambatan aplikasi, hambatan biaya, dan hambatan pasokan bahan baku. Berbeda dengan negara maju, partisipasi para pelaku utama sangatlah penting, terutama dari pemerintah, dalam pengembangan bahan baru untuk paket pangan.

Kata kunci: deskriptif kuantitatif, faktor penentu keberhasilan, industri pangan, kemasan makanan, tujuan pembangunan berkelanjutan

\footnotetext{
${ }^{1}$ Corresponding author:

Email: nyayu.lathifah@apps.ipb.ac.id
} 


\section{INTRODUCTION}

The issue of sustainability is getting more attention from the world authorities related to the issue of ensuring responsible consumption and production patterns, including food production. The mixture of sustainability and business practice significantly drives industries to take up nature strategies in their business model (Foschi, Zanni and Bonoli, 2020). Nowadays, food production deals with immense hindrance from sustaining food qualities to protecting weather conditions and environment (Neethirajan et al. 2018). These issues, as part of the sustainable development goals, increase food industry awareness, especially its destructive impact on the planet. The environment is one of the main zones which connected with influencing the development of eco-friendly packaging (Chisenga et al. 2020). The impact is concerning how food packaging, the shortrange products (Chapagain and Raizada, 2017), can transform towards a more sustainable future. Thus, the food industry is continuously looking for new materials to reduce and replace plastics in their packaging, for example, biopolymer composite (Salwa et al. 2020). Product packaging has been recognized by companies for a long time ago as a critical tool to increase sales (Kusumasondjaja, 2018). It can secure food, cause food able to be carried or moved, and communicates to markets (Muncke et al. 2020; Tiekstra et al. 2021). In Europe, Asia, and America, the consumers were mainly intending to make use of novel or sustainable food packages (Aday and Yener, 2015; Guiné et al. 2021). Currently, plastic, the non-biodegradable plastic packaging utility, and the daily use of plastic is the most significant contributor to the waste. It pushes all industries in the world to look for better packaging as the solutions for economics and society (Tariq, 2013). In developing countries, such as Indonesia, the authorities and industry enlarge their production because there is an opportunity not only in economic and social but also in environmental growths (Muzayanah et al. 2018) as known by the triple bottom line concept (Fahmi, 2012). An environmentally friendly packaging or commonly referred to as sustainable packaging has been utilized by the concerned food and beverage packaging industries, which discomfort by the issue of plastic as one of the primary pollutants of the ocean (Magnieret al. 2016).
The food packaging industry used plastics commonly (Bhogayata and Arora, 2019), even though it is hard to reuse, recycle, and moreover hazardous to the environment. In Indonesia, plastic waste reaches 26,500 tons per day (Juliastuti et al. 2017), and it makes this country ranked as the second country in the world with the most massive plastic waste (Purwoko, 2018) which will cause irreversible damage to the environment. Therefore, the development of new materials for packaging is essential. The utilization of wood is a useful material for packaging to substitute conventional plastics. Furthermore, paper material is one of the most popular packaging products derived from wood.

The recent development of novel materials tends to be more dynamic due to the different involvement from several vital players, namely government, society, and industry. Imposing a regulation from the government does not guarantee the revolution of food packaging towards sustainability. It is because sustainability involves various interests and abilities not only from the government but also from society and industry as well. The food packaging industry is depending on plastics, which is convenient (Clark et al. 2020). On the other hand, it raises worries relating to the economy and environment future. Thus, reducing and replacing plastic in food manufacturing is necessary. Indonesian authority demand is that each industry strives for reducing the volume of plastic waste consumed and produced. Moreover, industries across the country are also expected to apply an environmentally friendly system of plastic waste management towards sustainability future (Hidayat et al. 2016). Bashir et al. (2021) suggests that future studies might integrate the sense of responsibility to environmental care, support novel inventions, and start environmental care action.

A comprehensive analysis of the success factors for the key players' participation in sustainable food packaging under Indonesian circumstances has not been performed before. However, it becomes essential in sustainable food packaging development. Therefore, this study is aiming to describe the critical success factor of sustainable food packaging development in Indonesia with regard to the different key players' involvement, which are government, public, and industry. First, this paper covers the factors presented by several works of literature. Second, this paper analyzed the critical success factors among government, society, and industry. 


\section{METHODS}

This study utilized the quantitative approach with descriptive research. This study collected primary data through survey methodology and distributed the 1 to 5 Likert scale questionnaires to respondents. The survey conducted in Bogor, Indonesia, from January to March 2020. Around 25 respondents chosen used nonprobability sampling method and convenience sampling technique. The questionnaire consisted of two parts. The first part questioned the critical success factors and another part questioned the engagement steps of the main actors, specifically government, public, and industry. The first research questions investigated the critical success factors for the development of new material for food production package in Indonesia. These factors include technical substitution, technical drivers/barriers, application barriers, cost barriers, and raw material supply barriers. Table 1 describes each cluster, which listed as two to eight factors. Each cluster aimed to identify the priority factors to prepare the development of sustainable food packaging. These factors used to capture response, support, or awareness from each party towards new materials development.
Each cluster listed as two to eight factors. Factors or clusters with the highest score show essential factors or the priority factors to prepare the development of sustainable food packaging. The average Likert scale calculated by dividing the total Likert scale by the total number of respondents. The average cluster calculated by dividing the total average Likert scale of each cluster by the total number of factors in each cluster. Using the range of 0.8 , the rate classified into five groups, as follows 1.00-1.80: not at all important, 1.81-2.60: low importance, 2.61-3.40: neutral, 3.41-4.20: important, 4.21-5.00: very important.

The second part of questionnaire aimed to formulate and identify the priority measures from the involvement of three main actors in support of the development of environmentally friendly food packaging raw materials. The three main actors used in the study consisted of governments, industries, and communities. The details of each of the main actors' involvement listed in Table 2. Using the range of 0.8 , the rate classified into five groups, as follows 1.00-1.80: strongly disagree, 1.812.60: disagree, 2.61-3.40: neutral, 3.41-4.20: agree, 4.21-5.00: strongly agree.

Table 1. Critical success factors for developing sustainable food packaging

\begin{tabular}{ll}
\hline Cluster & Factors \\
\hline Technical Substitution & Value-added and economic impacts of developing raw materials \\
Technical driver/barrier & Market potential \\
& Institutional network \\
& The level of public and industrial awareness \\
& Government policy and commitment \\
Application barrier & Local and international advocacy \\
& Free market and international market segments \\
& Global dynamics and macroeconomics \\
& Intrinsic product \\
Cost barrier & Logistics infrastructure \\
& Innovation level and product competitiveness \\
Raw material supply barrier & Raw materials supply \\
& Availability of research and technology facilities and infrastructure \\
& Industry / business readiness \\
\hline
\end{tabular}




\section{RESULTS}

This research continued the previous study to identify the critical factors which essential for the new material development and participation in food packaging (Tirdasari et al. 2020). Based on the review of literature, the findings revealed that the critical success factors are classified into five clusters, namely technical substitution, technical drivers/barriers, application barriers, cost barriers, and raw material supply barriers. This research investigated those clusters and the result is shown in Table 3 .

Table 2. Engagement steps of the main actors

\begin{tabular}{ll}
\hline Actors & Factors \\
\hline Government & Arranges a movement program of sustainable food packaging \\
& Promotes the sustainable food packaging program to the public \\
& Provides a time limit for the public to replace the packaging with the sustainable one \\
& Provides sanctions to the public for not using sustainable food packaging \\
& Provides information on sustainable food packaging \\
& Works with various industries to facilitate the development of raw materials for sustainable \\
& food packaging \\
& Sanctioned when using non-sustainable food packaging \\
& Pays more for using sustainable food packaging \\
Public & Encouraged to bring rather than buying food with sustainable packaging \\
& Develops raw materials for sustainable food packaging \\
Given sanctions, if still uses non-sustainable food packaging \\
Able to produce affordable, sustainable food packaging \\
Given network access to be able to produce sustainable food packaging \\
Availability of research and technology facilities and infrastructure \\
Industry / business readiness \\
\end{tabular}

Table 3. Critical success factors for developing sustainable food packaging rate

\begin{tabular}{|c|c|c|c|c|}
\hline Cluster & Factors & $\begin{array}{l}\text { Avg. Likert } \\
\text { Scale }\end{array}$ & $\begin{array}{l}\text { Avg. } \\
\text { Cluster }\end{array}$ & Rate \\
\hline \multirow[t]{2}{*}{$\begin{array}{l}\text { Technical } \\
\text { Substitution }\end{array}$} & $\begin{array}{l}\text { Value-added and economic impacts of developing } \\
\text { raw materials }\end{array}$ & 4.44 & & \\
\hline & Market potential & 4.44 & 4.44 & Very important \\
\hline \multirow{3}{*}{$\begin{array}{l}\text { Technical driver/ } \\
\text { barrier }\end{array}$} & BPOM certification system & 4.60 & & \\
\hline & Institutional network & 3.92 & & \\
\hline & The level of public and industrial awareness & 4.40 & 4.31 & Very important \\
\hline \multirow[t]{4}{*}{ Application barrier } & Government policy and commitment & 4.60 & & \\
\hline & Local and international advocacy & 4.32 & & \\
\hline & Free market and international market segments & 3.88 & & \\
\hline & Global dynamics and macroeconomics & 4.00 & 4.20 & Important \\
\hline \multirow[t]{3}{*}{ Cost barrier } & Intrinsic product & 4.44 & & \\
\hline & Logistics infrastructure & 4.12 & & \\
\hline & Innovation level and product competitiveness & 4.56 & 4.37 & Very important \\
\hline \multirow{3}{*}{$\begin{array}{l}\text { Raw material supply } \\
\text { barrier }\end{array}$} & Raw materials supply & 4.52 & & \\
\hline & $\begin{array}{l}\text { Availability of research and technology facilities } \\
\text { and infrastructure }\end{array}$ & 4.52 & & \\
\hline & Industry / business readiness & 4.24 & 4.43 & Very important \\
\hline
\end{tabular}


The findings highlighted the essential factor for each cluster that determined the factors for sustainable food packaging development. Among the technical substitution clusters, value-added and economic impacts of developing raw materials as well as market potential were the essential factors. Among the technical driver/ barrier cluster, the most essential factor was the BPOM certification system. Among the application barrier cluster, government policy and commitment were the essential factor. Among the cost barrier cluster, the innovation level and product competitiveness were the essential factor. Among the raw material supply barrier cluster, raw materials supply, as well as the availability of research and technology facilities and infrastructure, were the essential factors. Among all clusters, technical substitution was the most essential cluster as seen in Figure 1. This research investigated the priority measures from the involvement of three main actors and the result is shown in Table 4.

Based on the results, the government endorses an environmentally friendly food packaging movement program was the most essential factor within the government as seen in Figure 2. On the public side, the most essential factor was communities encouraged to bring/provide food containers made from environmentally friendly materials rather than buying food with eco-friendly packaging as seen in Figure 3. Moreover, within the industry, industry conducts the development of raw materials for eco-friendly food packaging was the essential factor as seen in Figure 4. Among all actors, the industry was the key player for sustainable food packaging development.

The research employed a Likert scale to measure the agreement and importance of the particular statements listed on the questionnaire. Based on the findings, the critical success factors in technical substitution were the value-added and economic impact of raw material development as well as market potential. Nevertheless, other key factors influenced the development of sustainable food packaging. The critical success factors in technical drivers or barriers are the BPOM certification system. Certification is crucial before commercializing the sustainable food packaging to the market because many consumers in Indonesia have concerned about such certifications to their food. The critical success factors in the application barrier are government policies and commitments. In order to raise the effectiveness of the development, policy, and commitment of the authority is essential. The critical success factor in the cost barrier is the level of innovation and product competitiveness. For some industries, the cost to develop sustainable packaging is high, so that demand innovation. The critical success factor in the raw material supply barrier was the availability of raw materials as well as research and technology facilities and infrastructure. Research and technology are required to overcome the risk of raw material supply (Tariq, 2013).

Table 4. Engagement steps of the main actors rate

\begin{tabular}{|c|c|c|c|c|}
\hline Actors & Factors & $\begin{array}{l}\text { Avg. Likert } \\
\text { Scale }\end{array}$ & $\begin{array}{l}\text { Avg. } \\
\text { Actors }\end{array}$ & Rate \\
\hline \multirow[t]{6}{*}{ Government } & Arranges a movement program of sustainable food packaging & 4.36 & & \\
\hline & Promotes the sustainable food packaging program to the public & 4.24 & & \\
\hline & $\begin{array}{l}\text { Provides a time limit for the public to replace the packaging with the } \\
\text { sustainable one }\end{array}$ & 4.16 & & \\
\hline & $\begin{array}{l}\text { Provides sanctions to the public for not using sustainable food } \\
\text { packaging }\end{array}$ & 3.60 & & \\
\hline & Provides information on sustainable food packaging & 4.32 & & \\
\hline & $\begin{array}{l}\text { Works with various industries to facilitate the development of raw } \\
\text { materials for sustainable food packaging }\end{array}$ & 4.32 & 4.17 & Agree \\
\hline \multirow[t]{3}{*}{ Public } & Sanctioned when using non-sustainable food packaging & 3.40 & & \\
\hline & Pays more for using sustainable food packaging & 3.12 & & \\
\hline & $\begin{array}{l}\text { Encouraged to bring rather than buying food with sustainable } \\
\text { packaging }\end{array}$ & 4.08 & 3.53 & Agree \\
\hline \multirow[t]{4}{*}{ Industry } & Develops raw materials for sustainable food packaging & 4.40 & & \\
\hline & Given sanctions, if still uses non-sustainable food packaging & 4.20 & & \\
\hline & Able to produce affordable, sustainable food packaging & 4.28 & & \\
\hline & Given network access to be able to produce sustainable food packaging & 4.28 & 4.29 & $\begin{array}{l}\text { Strongly } \\
\text { agree }\end{array}$ \\
\hline
\end{tabular}




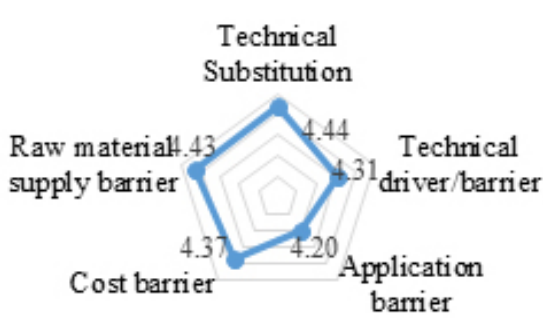

Figure 1. Average cluster score

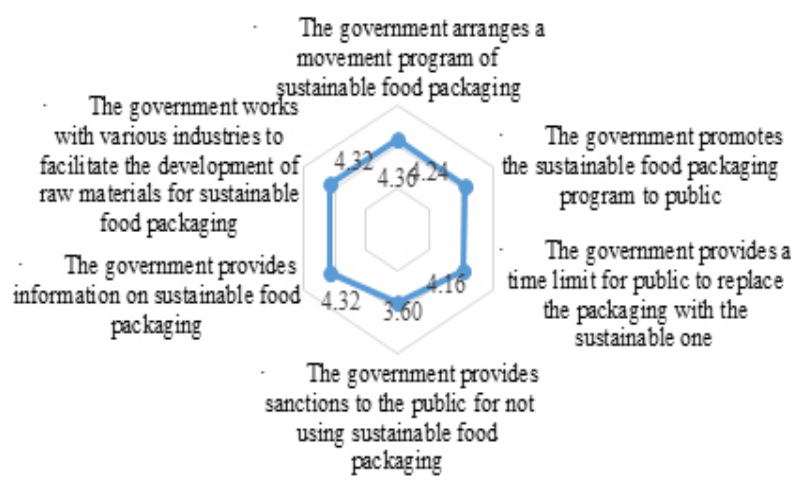

Figure 2. Government score

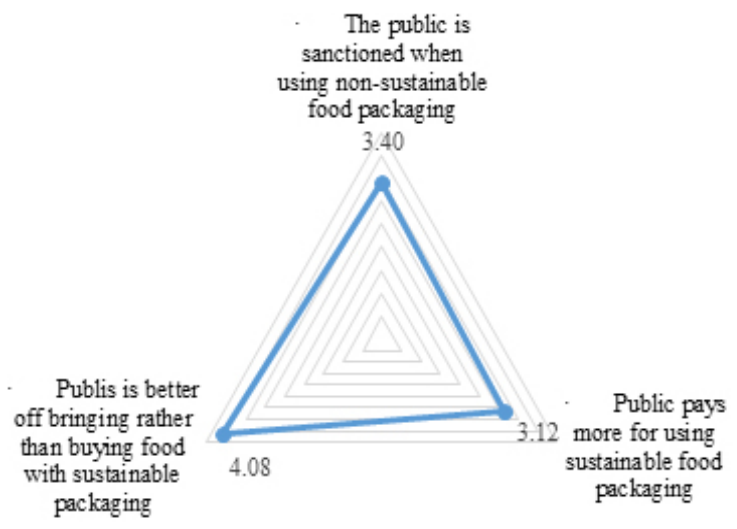

Figure 3. Public score

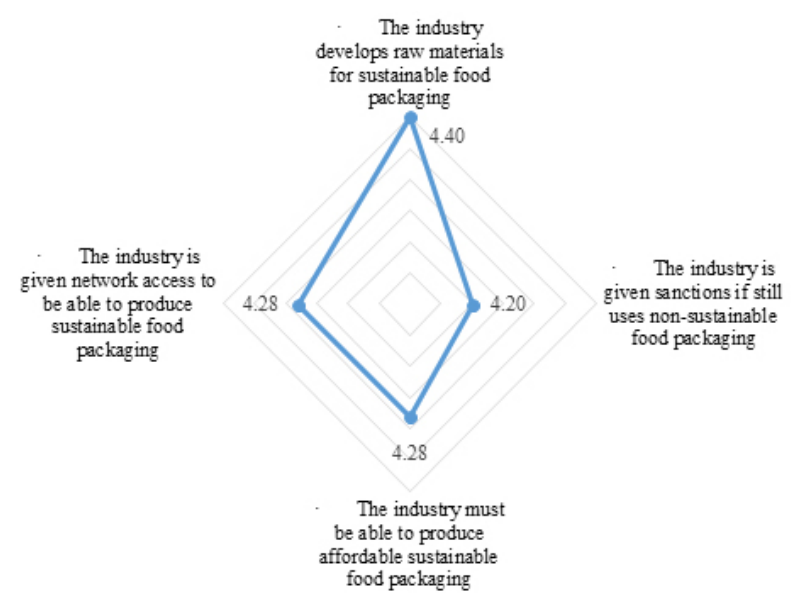

Figure 4. Industry score
The public in Indonesia surveyed to gather data to test the factors identified by the literature review on the impact of the actors' participation in sustainable food packaging development. The research utilized a Likert scale to analyze the criteria. The essential factor in explaining the government participation effect in developing the sustainable food packaging was the government endorses an environmentally friendly food packaging movement program. Moreover, there is one factor which critical to explain public involvement, which was communities encouraged to bring/ provide food containers made from environmentally friendly materials rather than buying food with ecofriendly packaging. Lastly, the industry conducts the development of raw materials for eco-friendly food packaging was critical for industry involvement. Among all actors' engagement, the industry was the key player for sustainable food packaging development. As the key player, it means the industry holds a crucial role in developing the novel material.

\section{Managerial Implications}

This research has the following business implications for food packaging industries: (1) Food packaging industries must be able to produce innovative and environment friendly packaging and (2) Food packaging industries must be able to collaborate either with public or government to become more responsible to nature. The implications of the government related to this research include that: (1) Government must draw up policies in developing sustainable food packaging and (2) Government must be able to facilitate agendas to promote healthy and sustainable lifestyle to public more often.

\section{CONCLUSIONS AND RECOMMENDATIONS}

\section{Conclusions}

This research revealed several critical factors regarding the sustainable food packaging development. These factors expected to assist the key players in Indonesia in assembling the decisions. This study highlights theoretical factors to develop sustainable food packaging may include technical substitution, technical driver/ barrier, cost barrier, and raw material supply barrier. It is essential to improve the critical success factors within the key players, which are government, public, and industry. The key factors affecting the government 
are the movement program arrangement, the promotion program, and the facilities. The key factors affecting the public and industry are bringing rather than buying food with a sustainable package and network access, sequentially. In Indonesia, the involvement of key players, especially from the government, was essential in developing new material for food packages. This research constructs the factors through literature analysis and then empirically verify the factors through a questionnaire survey. Furthermore, this study conducted as a contribution to the development of new material in the context of a food production package. The government expected to have a significant effect on the development of new material, with the public placed second. However, according to the findings, the industry holds a crucial role in developing novel material. Besides, this study may avail governments to draw up policies in developing sustainable food packaging.

\section{Recommendations}

Finally, we proposed recommendations to enhance further the government participation in sustainable food packaging development through setting up program to drive public and industry concerning the sustainable food packaging, for example. Appealed to universities to build up entrepreneurial competences to create innovative food packaging. In addition, protect consumers from hazardous materials in food packaging.

\section{REFERENCES}

Aday MS, Yener U. 2015. Assessing consumers' adoption of active and intelligent packaging. British Food Journal 117(1):157-177. http:// dx.doi.org/ 10.1108/BFJ-07-2013-0191.

Bashir S, Khwaja MG, Mahmood A. 2021.Mores of the customer base for ecotourism industry: Development and validation of a new measurement scale. PLoS One 16(2):1-7. http:// dx.doi.org/10.1371/journal.pone.0246410.

Bhogayata AC, Arora NK. 2019. Utilization of metalized plastic waste of food packaging articles in geopolymer concrete. Journal of Material Cycles and Waste Management 21(4):1014-1026. http:// dx.doi.org/10.1007/s10163-019-00859-9.

Chapagain T, Raizada MN. 2017. Impacts of natural disasters on smallholder farmers: gaps and recommendations. Agriculture \& Food Security 6(39):1-17. http://dx.doi.org/10.1186/s40066017-0116-6.

Chisenga SM, Tolesa GN, Workneh TS. 2020. Biodegradable Food Packaging Materials and Prospects of the Fourth Industrial Revolution for Tomato Fruit and Product Handling. International Journal of Food Science 2020:1-17. http:// dx.doi.org/10.1155/2020/8879101.

Clark N, Trimingham R, Wilson GT. 2020. Incorporating Consumer Insights into the UK Food Packaging Supply Chain in the Transition to a Circular Economy. Sustainability, 12(15):1-32. http:// dx.doi.org/10.3390/su12156106.

Fahmi I. 2012. SUSTAINABLE BUSINESS COMPETITIVENESS: TRANSLATING CONCEPT INTO PRACTICE. Jurnal Manajemen \& Agribisnis 9(Edisi Khusus):1-5. doi: https://doi.org/10.17358/jma.9.2.1-5.

Foschi E, Zanni S, Bonoli A. 2020. Combining EcoDesign and LCA as Decision-Making Process to Prevent Plastics in Packaging Application. Sustainability 12(22):1-13. http://dx.doi. org/10.3390/su12229738.

Guiné RPF. et al. 2021. Environmental Issues as Drivers for Food Choice: Study from a Multinational Framework. Sustainability 13(5):1-18. http:// dx.doi.org/10.3390/su13052869.

Hidayat YA, Kiranamahsa S, Zamal MA. 2016. A study of plastic waste management effectiveness in Indonesia industries. AIMSEnergy 7(3):350-370. http://dx.doi.org/10.3934/energy.2019.3.350.

Juliastuti SR et al. 2017. Microwave pyrolysis of multilayer plastic waste (LDPE) using zeolite catalyst', in AIP Conference Proceedings. American Institute of Physics Inc., p. 110001. doi: 10.1063/1.4982331.

Kusumasondjaja S. 2018. View of Comparing the Effectiveness of Information Framing Strategy on Utilitarian and Hedonic Food Product Packaging. Jurnal Manajemen \& Agribisnis 15(1):44-52. http://dx.doi.org/10.17358/jma.15.1.44.

Magnier L, Schoormans JP, Mugge R. 2016. Judging a product by its cover: Packaging sustainability and perceptions of quality in food products', Food Quality and Preference, 5:132-142. http:// dx.doi.org/10.1016/j.foodqual.2016.06.006.

Muncke J. et al. 2020. Impacts of food contact chemicals on human health: a consensus statement. Environmental Health 19(25): 1-12. http://dx.doi.org/10.1186/s12940-020-0572-5. 
Muzayanah FN, Cahyadi ER, Munandar JM. 2018. Dynamic Modelling System of Indonesia's Crude Palm Oil Sustainable Supply Chain Management. Jurnal Manajemen \& Agribisnis 15(1):33-43. http://dx.doi.org/10.17358/jma.15.1.33.

Neethirajan S et al. 2018. Biosensors for Sustainable Food Engineering: Challenges and Perspectives. Biosensors 8(23):1-35. http://dx.doi. org/10.3390/bios 8010023 .

Purwoko TW. 2018. FISCAL INCENTIVES AND DISINCENTIVES TO REDUCE PLASTIC WASTE IN INDONESIA', in Wibowo, C. P. (ed.) ASEAN/Asian Academic Society International Conference Proceeding Series. Thailand: PERMITHA, pp. 213-218.

Salwa, H. N. et al. (2020. Conceptual Design and Selection of NaturalFibre ReinforcedBiopolymer Composite (NFBC) Takeout Food Container. Journal of Renewable Materials 9(4):803-827. http://dx.doi.org/10.32604/jrm.2021.013977.

Tariq, S. 2013. Success factors for the adoption of biobased packaging in EU food industry', p. 82.

Tiekstra S et al. 2021.Holistic Approach to a Successful Market Implementation of Active and Intelligent Food Packaging. Foods 10(2):1-22. http:// dx.doi.org/10.3390/foods10020465.

Tirdasari NL et al. 2020. The Development of New Material for Food Production Package in Indonesia: Proposed Key Success Factors', in Fahmi, I. (ed.) Proceedings of the First ASEAN Business, Environment, and Technology Symposium (ABEATS 2019). Paris, France: Atlantis Press, pp. 124-126. http://dx.doi. org/10.2991/aebmr.k.200514.028. 